\title{
Oenothera humifusa
}

\section{seabeach evening primrose}

\section{Onagraceae}

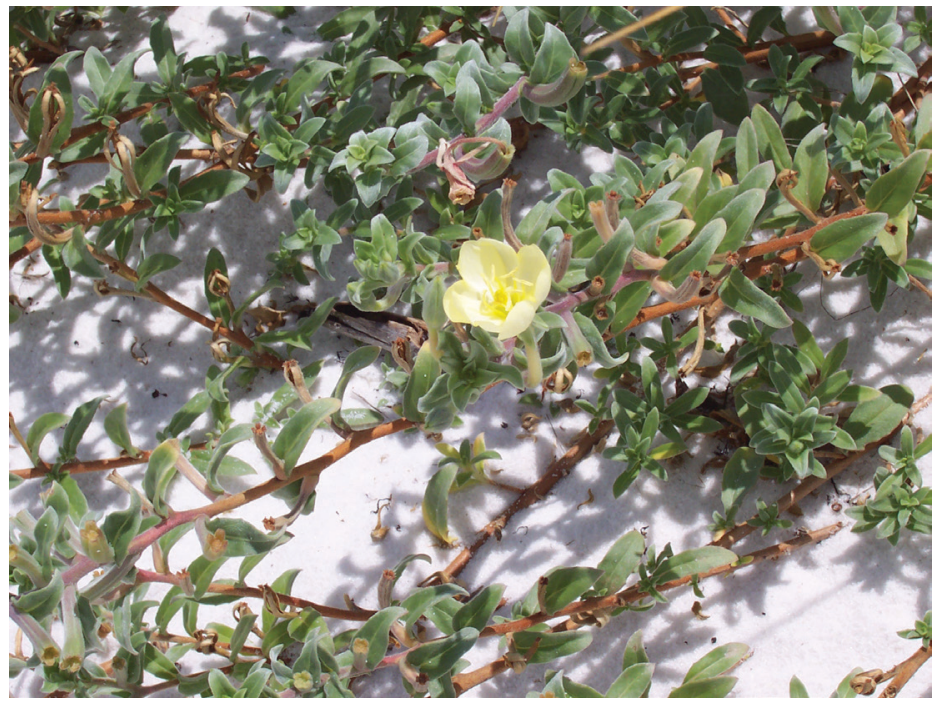

Credit: Josiah Raymer, UF/IFAS

Seabeach evening primrose is found in beach dunes throughout coastal counties in Florida, west to Louisiana, and as far north as New Jersey.

\section{General Description}

Seabeach evening primrose is an herbaceous perennial with horizontal stems forming a rounded, mounding canopy. Leaves are simple and alternate and wider than $1 \mathrm{~mm}$ with short, silky pubescence. Stems are prostrate, grow up to 3 $\mathrm{ft}$ long, and are covered with silky appressed pubescence. Flowers are axillary with 4 yellow petals that are 0.2 to 0.6 in long, 4 sepals that are 0.1 to 0.4 in long, and flattened bracts. They have a hypanthium that is longer than the ovary. Fruits are 10- to 35-mm-long dehiscent capsules with appressed hairs that give rise to numerous rounded seeds.

\section{Propagation}

No published seed propagation information is presently available for O. humifusa; however, other Oenothera species are well studied and have been shown to require light to germinate (Greiner and Köhl 2014). The authors collected stem cuttings in the fall and found the seeds present within the capsules already on the cuttings readily germinated in propagation flats under intermittent mist and natural photoperiod post-dehiscence. Seedlings initially form a low, broad rosette and are easily transplanted as small plugs after two weeks' growth in the propagation flat. Seedling growth is eventually lateral becoming multibranched. Seedlings will fill 4 -in pots in 4 weeks when grown outdoors with overhead irrigation and fertilized with slow-release fertilizer.

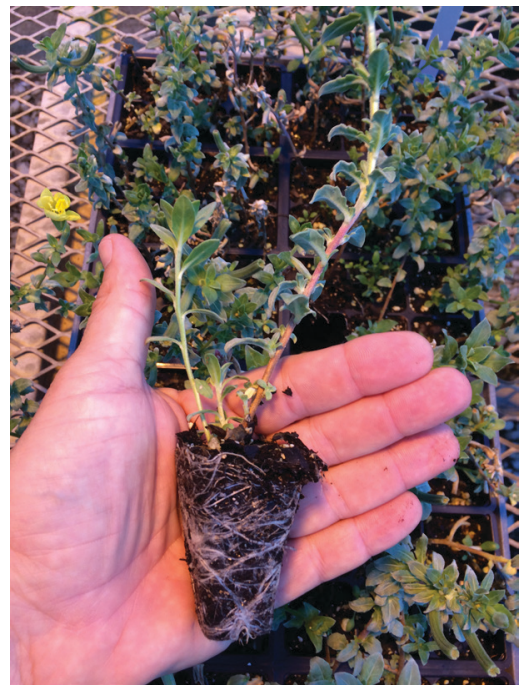

Credit: Mack Thetford, UF/IFAS
The authors found stem cuttings of Oenothera rapidly and readily produce roots without auxin application. Apical stem cuttings taken in late April 2017 from Santa Rosa Island, Florida, rooted and filled 162-cell flats in less than 4 weeks while under intermittent mist and natural photoperiod in a controlled-environment greenhouse. Cuttings grown in 72-cell flats filled 4-in pots in 4 weeks when grown outdoors under overhead irrigation and fertilized with slow-release fertilizer.

In nursery culture, this plant may become infested with flea beetles (Altica sp). The preferred plant hosts of this insect are likely limited to the members of the evening primrose family, Onagraceae (Clark et al. 2004). The beetle is a problem on Oenothera in the spring (May-June in north Florida) when larvae and adults appear in large numbers and can feed on the host plant until it dies. The authors have not noted this insect to be a serious pest of Oenothera growing within coastal plant communities, likely related to

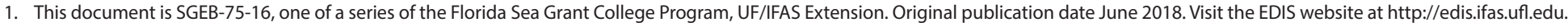

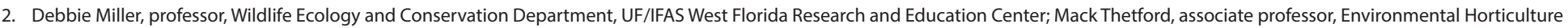

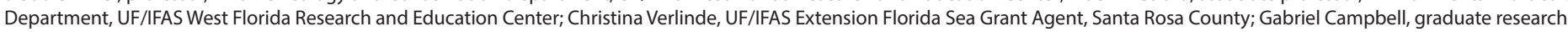

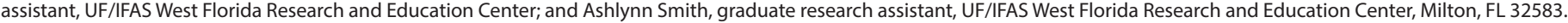


the harsh environment and presence of natural enemies. Commercial pest management recommendations are available to manage the pest in nursery culture.

\section{Outplanting}

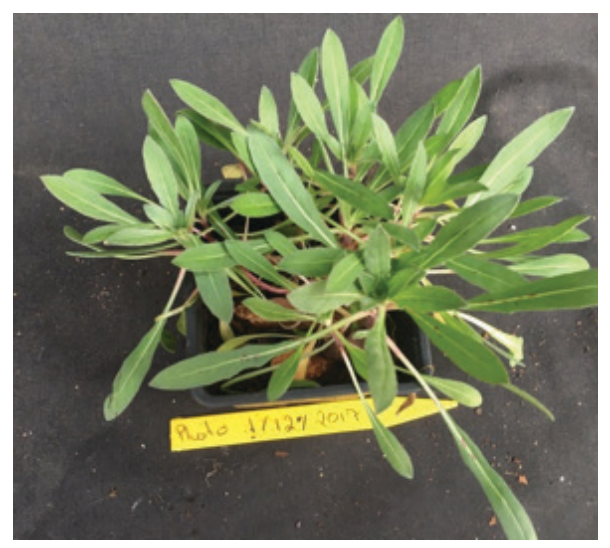

Credit: Steven Wagner, UF/IFAS
Plants in 4-in pots with fully developed rootballs and canopies have successfully been outplanted by the authors. In a preliminary trial, when planted in July on open beach areas behind low frontal dunes, transplant success was $43 \%$. However, in subsequent plantings in early March survival was $100 \%$ after 2 months. Plants were outplanted on backdunes midslope at least 12 in from each other and existing perennial grasses. Fertilizer application ( $1 / 2$ tsp Osmocote 18-6-12) improved the aesthetic appearance of plants and increased biomass for this plant but was not necessary for survival.

\section{Literature Cited}

Clark, S.M., D.G. LeDoux, T.N. Seeno, E.G. Riley, A.J. Gilbert, and J.M. Sullivan. 2004. "Host plants of leaf beetle species occurring in the United States and Canada (Coleoptera: Megalopodidae, Orsodacnidae, Chrysomelidae exclusive of Bruchinae)." Coleopterists Society, Special Publication no. 2. 476 pp.

Greiner, S., and K. Köhl. 2014. "Growing evening primrose (Oenothera)." Frontiers in Plant Science. 5(38):1-12. 